\title{
Industrialization of Small Medium Enterprises
}

(a Phenemenological Study on Rattan Cluster Industry in Cirebon, Indonesia)

\author{
Asngadi \\ Tadulako University, Palu \\ asngady@yahoo.com
}

\author{
Mas'adah \\ Darul ‘Ulum University, Jombang
}

\begin{abstract}
This research aims to identify industrialization pattern of rattan SMEs cluster in Cirebon, West Jawa, Indonesia. Non-mainstream paradigm has been applied in this research using Schutz phenomenology analysis method. Data analysis employs in this study is Nvivo 11. The results show that a socio-historical product serves as a base for cluster development of small and medium-size businesses in Cirebon Regency. Industrialization process of rattan SMEs cluster has been determined using quadruple helix (four actors) involving academic, business, community, and government. The activity industrialization of SMES rattan industry included design strengthening, government support, capacity building, market facilitation, maklun culture strengthening.
\end{abstract}

Keywords: cluster, rattan, industrializaion of SMEs, quadruple helix (4 actors)

\section{INTRODUCTION}

One of clusters of SMEs in Indonesia which has an international competitiveness is rattan industries in Cirebon regency, West Java Indonesia. Nowadays, the cluster have produced about $80 \%$ of national export rattan furniture (FT Link Consultant - SHK Kaltim, May, 2005). Due to its large impact of this industry, rattan industries have been determined as the Regional Industrial Competence since 2011. Historically, rattan industrial clusters in Cirebon Regency grew up from only one cluster, namely Tegalwangi cluster. Nowadays, it has increased up to 11 clusters [1]. Since Indonesia government released regulation to ban raw rattan exports in 2011, furniture industry has developed rapidly.

The growth of rattan industrial clusters in Cirebon Regency is different from the findings of Smith's [2], in which the rattan industry in Assam (India) traditionally grow up in rattan or bamboo. Asngadi's study [3] found that strength of sociohistorical development of the Cirebon rattan SME's cluster is on its industries.

Cluster development in Cirebon Regency through the industrialization is a phenomenal evidence. The Cirebon regency grows to become a national's rattan industrial cluster. Otherwise, producers of raw materials in Central Sulawesi, the cluster has not grown up yet [4]. The process of industrialization of
SMEs in Cirebon regency has been analyzed in revealing the successful development of clusters, and can be applied to develop 25,000 potential clusters in Indonesia [5].

The popular concept of developing cluster is diamond model [6]. However, there is an antithesis of this model, because the model is not suitable for the third world, so cluster development must be viewed from a dynamic perspective of policy, social and economic aspects [7]. Another pattern in cluster development is top down model which has been applied in China [8]. Development of industrial clusters in Indonesia is attractive, because of the communality of Indonesian society [9]. Thus, this research is different from several previous studies which adopted western concepts.

\section{METHOD}

The research paradigm used in this research is postpositivism [10], [11], which is based on the existence of unique phenomenon, wherein Cirebon Regency did not have resources. However, nowadays it has become a national cluster of rattan [12], [13].

Setting of this research was conducted in Cirebon Regency. The role of triple helix actors: academics, businesses, government in developing cluster become point of view of discussion. Snowballing method was used this research in determining informants.

This research employs data validity test as directed by Guba in [14] consisting of credibility, transferability, dependability, confirmability.

The steps of data analysis have been done based on rule proposed by Kuswarno [15] that is description of data; data horizonalization; textual description; structural description; construction of meaning; and composite description

\section{RESULT AND DISCUSSION}

\section{MIND MAP}

Data have been analyzed using Nvivo 11 software. Based on data analysis, it can be assembled into a mind map that describes the pattern of data found in the field. Data findings reflected how the theme and sub theme has related to developing SME clusters in Cirebon regency.

The mind map of the research provides Figure 1 . 


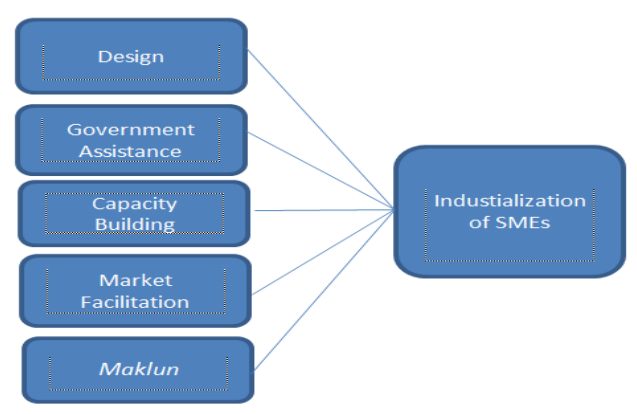

Figure 1. Mind map of the result

Mind map in Figure 1 provides comprehesiveness that the development of SME clusters in Cirebon regency was established through various activities related to industrialization of rattan SMEs in Cirebon Regency.

\section{DISCUSSION}

Potential clusters should be developed so that clusters can move more dynamically. The process of "industrialization" of clusters is how to develop communal skills and artisans, moving to be a better cluster (dynamic cluster or advanced cluster).

Based on the results of field data analysis, themes are found and they are the keywords of industrialization SMEs Rattan Industry in Cirebon District.

Design

Strengthening the rattan design for SME clusters is intended to analyse and map craftsman's abilities. Its strength determines the design of furniture that has competitiveness, based on the natural ability of businessman [9]. This is in accordance with the statement of informant:

Prof. Imam Buchori (ITB -Bandung Technology of Institutes), who first made the product design in Indonesia. Prof Imam Buchori's direct design and industry was ready to be operated, because the raw material had been available. In 1990's, production volume was high. Even 24 hours production system until the remote village .... that's the staple gun goes until morning.. (AN)

The better design, at least we still have a profit.. so we try to explain this fact to the businessman. Well.. that's our first intervention in Cirebon industry, with the ministry of industry. (AN)

\section{Government Assistance}

The development of rattan industrial cluster in Cirebon Regency is a policy approach. As part of the policy, the determination of a product that has social value, will be followed by various government policy appropriately. The informant said :

..indeed Ministry of Worker providing new training, also provides equipment. Recently, there are 16 new ventures got equipments (SO).
We are, in last year, got 10 billion aid, from West Java government. Later, we conduct mapping the new venture, and it is then evaluated by inspectorate depatment, to make sure that SMEs formed be able to operated (DD).

Various findings on the development of SMEs in clustering basis as pointed out by Hill [16], Tambunan [17], [18], Weijland [19] justified that the government has a strong effort to develop SMEs based on the clusters.

\section{Capacity Building}

Skill of weaving is the core in the SMEs cluster in Cirebon Regency. However, capacity building is still needed to increase the basic capability to international market of rattan furniture. The informant states that:

Once in the 70's rattan has not been colored. After being trained in ITB, we began to have a rattan in the drag / scratch, drawn. That's training from ITB, so the color can stick. It used to be all rattan. (SU)

Upgrading skills such as bending techniques, coloring, finishing are skills that are developed to enter international market industries. In addition, the attitude of SMEs entrepreneurs to enter in the international market must also be built. The successful development of SMEs cluster through capacity building can be seen from the evident in EU experience through the JEREMIE agency [20].

\section{Market Facilitation}

Development of SME clusters should be able to create of high demand pull (the domestic and international market). The advanced cluster is characterized by its ability to enter into global business and international markets [21]. The informant said:

In 1986, only the number of businessman is dozens. In 1991, the number of entrepreneurs grew up to 581, raised thousands percent. Banking in the past asking how much do you want for funding? Hotel is given, tickets are given. Lumpsum 100 dollars a day. But the result is ok .. right. (SO)

Yesterday, we conducted business matching with the Germany Chamber of Commerce, Germany businessmen. The participant from Cirebon included KADIN (Commerce and Industrial Association of Indonesia), rattan business. (SUR)

The market facilitation undertaken in developing SME cluster in exhibition in Cirebon regency is a government funding. Besides exhibition, the building market of SME is done through business matching. Business matching is part a series of exhibition events and focused on a meeting between business and associations of two countries or more.

\section{Maklun}

The dynamic process in development of SME cluster in Cirebon Regency happened when there was a shifting of production patterns. The production process has changed from individual patterns to 
maklun pattern. Until now, the maklun pattern grows up in clusters.

In manufacturer point of view, maklun is a factory-educated workforce. Meanwhile from businessman point of view, the maklun means improving capacity of production. The maklun process in Cirebon regency shows the perfect knowledge sharing from large manufacturers to their supporting business units. An informant said :

Originally, the maklun is an employee, then assigned by the company to operate at home. So maklun is the results of the company's upgrading to get larger production scale. And then the maklun got funding tools such as compressor (DA)

... there is a factory such as Bella Donna belonging by Haji Bali. In the past Haji Bali is employee of Khalim, and now to become a big factory. Formerly, he was a Khalim's employee, then resigned and to be maklun. Now his factory is big. (SU)

\section{Model of SMEs Development Cluster in Cirebon Regency}

Developing of rattan SMEs cluster in Cirebon has been conducted by various stakeholders involving academic, business, and government.

Several activity directly related in cluster development included developing of design, increased government assistance, capacity building, market initiation, and strengthening maklun culture.

Developing cluster industries are based on core competencies namely socio-historical products [3]. Thus, successful industrialization of SMEs should be based on a basic strength in the community. Thus, the model of developing of rattan industrial SMEs cluster provided in Figure 2.

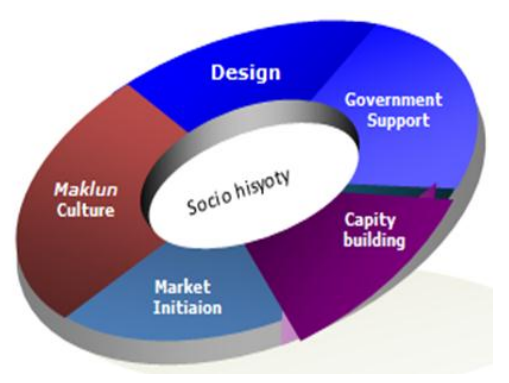

Figure 2. Model of SMEs Development Cluster

\section{CONCLUSION}

Based on empirical data analysis, this research concludes that:

1. developing of rattan SMEs cluster in Cirebon regency is based on the basic strength, that is socio-historical factors of rattan.

2. sosio-historical factors of rattan, both technically and socially make the locals genuine which is not easy to be adopted and imitated by others. Finally, a strong socio- historical factor of product is forming a basis of cluster in Cirebon regency.

3. the development of SME clusters in Cirebon Regency is the result of industrialization and collaborative proses among actors namely Academic, Business, and Government.

4. specific activities in industrialization process of SMEs in Cirebon Regency are joint activities including design training, government assistance and funding, skill and managerial upgrading for SMEs, appropriate technology, capacity building, community empowerment, market facilitation through exhibitions, strengthening the production strategy through empowering of maklun culture.

\section{REFERENCES}

[1] Dinas Perindustrian Dan Perdagangan Kabupaten Cirebon; Data Industri Rotan Kabupaten Cirebon, Kabupaten Cirebon. 2014

[2] Smith, Joan, Evaluation Of Management And Marketing Of Rattan Products In Assam, Theses, Master Of Natural Resources Management, The University Of Manitoba Winnipeg, Manitoba, Canada. 1997

[3] Asngadi, Model Strategi Pebngembangan Klaster UKM di Kabupaten Cirebon, Disertasi, Program Doktor Ilmu Manajemen, Fakultas Ekonomi dan Bisnis Universitas Brawijaya. 2017

[4] Sulteng Post, Menteri Perindustrian Resmikan Pirnas Palu, Sulteng Post, 8 Desember 2014. Diakses 14 Pebruari 2015.

[5] Sandee, H. and ter Wengel, J., SME cluster development strategies in Indonesi, paper presented at JICA workshop on strengthening capacity of SME clusters in Indonesia, 5-6 March, Jakarta. 2002

[6] Porter, M.E., The Competitive Advantage of Nations. New York. 1990

[7] Parrilli, Mario D, A Stage and Eclectic Approach to Industrial District Development: Two Policy Keys for 'Survival' Clusters in Developing Countries, European Planning Studies, Vol. 12. 2004

[8] Liu, Zhe, Yong Geng, Pan Zhang, Huijuan Dong, Zouxi Liu, Emergy Based Comparative Industrial Cluster : Economic And Technological Development Zone Of Shengyang Area, China, Environ Sci Pollut Res, 21 : 10243-10253. 2014

[9] Sriwarno, Andar Bagus and Imam Damar Djati, Enhancing Local Designers Skill in Rattan Furniture Industries in Cirebon through Comprehensive-Design Approach Regarding Buyers' Dependencies Prevention. ITB J. Vis. Art and Des., Vol. 3, No. 2, 175-186. 2009 
[10] Creswell, John W, Qualitative inquiry and And Research design, Choosing among five Approaches., Sage Publication. 2007

[11] Guba, E.G., and Lincolin, Y.S., Competing Paradigms in Qualitative Research, In N.K. Denzin and Y.S. Lincolin (Eds). Handbook of Qualitative Research. Thousand Oaks : SAGE, Publication, Ltd. USA. 1994

[12] Salladien, Rancangan Penelitian Kualitatif. Lembaga Penelitian. Departemen Pendidikan Nasional Universitas Negeri Malang. Malang. 2004

[13] Riyadi, Daya Saing Daerah Tujuan Wisata (Studi Kasus Rendahnya Daya Saing Taman Wisata Alam Kawah Ijen Banyuwangi), Disertasi Program Doktor Ilmu Manajemen, Pascasarjana Fakultas Ekonomi Dan Bisnis Universitas Brawijaya Malang. 2012

[14] Fatchan, A., Metode Penelitian Kualitatif, 10 Langkah Penelitian Kualitatif Pendekatan Konstruksi Dan Fenomenologi, Universitas Negeri Malang Press, Malang. 2013

[15] Kuswarno, Engkus, Fenomenologi, metode penelitian komunikasi, konsepsi, pedoman dan contoh penelitian, penerbit Widya Padjaajaran, Bandung. 1999
[16] Hill, H., Old Policy Challenges For A New Administration: SMEs in Indonesia, in $\mathrm{C}$. Harvie and B.-C. Lee (eds.), The Role of SMEs in National Economies in East Asia, Cheltenham: Edward Elgar, 158-80. 2001

[17] Tambunan, T., Development of SMEs In A Developing Country: The Indonesian Story, Journal Of Business And Entrepreneurship., vol.19, pp.6078. 2007

[18] Tambunan, T., Trade Liberalization effects on the development of small and mediumsized enterprises in Indonesia : A case study, Asia-Pacific Development Journal vol.15 pp.35-59. 2008

[19] Weijland, H., Microenterprise Clusters In Rural Indonesia: Industrial Seedbed And Policy Target, World Development, Vol. 27, pp. 1515-30. 1999

[20] http://www.sme.go.th, 2016.

[21] Mawardi, Mukhammad Kholid, Model Pengembangan Usaha Kecil Dan Menengah (UKM) Dengan Pendekatan Kluster, terdapat pada http://ejournal.uinmalang.ac.id/index.php/ekonomi/article/view $\underline{1299 .} 2009$ 